\title{
Vaginal Cancer TNM Finding v8
}

National Cancer Institute

\section{Source}

National Cancer Institute. Vaginal Cancer TNM Finding v8. NCI Thesaurus. Code C139632.

A finding about one or more characteristics of vaginal cancer, following the rules of the TNM AJCC v8 classification system. This classification system applies to all carcinomas of the vagina. There is no AJCC staging system for mucosal melanoma of the vagina. (from AJCC 8th Ed.) 